Yvonne McElarney

(corresponding author; email: yvonne. mcelarney@afbini.gov. uk. ORCID iD: https:// orcid.org/0000-00024772-4650), Agri-

Food and Biosciences Institute, 18a Newforge Lane, Belfast, BT9 5PX, Northern Ireland; Brian Rippey, School of Geography and Environmental Sciences, Ulster University, Cromore Road, Coleraine, BT52 1SA, Northern Ireland Claire Miller, School of Mathematics and Statistics, University of Glasgow, University Avenue, G12 8QQ, Scotland; Michelle Allen, Agri-Food and Biosciences Institute, 18a Newforge Lane, Belfast, BT9 5PX, Northern Ireland; and Antony Unwin, Mathematics Institute, University of Augsburg, 86135 Augsburg, Germany.

Cite as follows: McElarney, Y., Rippey, B., Miller, C., Allen, M. and Unwin, A. 2021 The long-term response of lake nutrient and chlorophyll concentrations to changes in nutrient loading in Ireland's largest lake, Lough Neagh. Biology and Environment: Proceedings of the Royal Irish Academy 2021. DOI: 10:3318/ BIOE.2021.04

Received 22 September 2020. Accepted 11

December 2020

Published 29 April 2021.

\title{
THE LONG-TERM RESPONSE OF LAKE NUTRIENT AND CHLOROPHYLL CONCENTRATIONS TO CHANGES IN NUTRIENT LOADING IN IRELAND'S LARGEST LAKE, LOUGH NEAGH
}

\author{
Yvonne McElarney, Brian Rippey, Claire Miller, \\ Michelle Allen and Antony Unwin
}

\begin{abstract}
The long-term response of chlorophyll- $a$ (chl-a) to changing lake water nutrient concentrations and increasing water temperature was investigated in Lough Neagh, a large, hypereutrophic lake in Northern Ireland. Trends in external and internal nutrient loading and their relation to lake nutrient concentrations were also established. Lake water concentrations of total P (TP) have increased since the 1990s but were not correlated with catchment inputs, which showed no trend. The characteristics of internal loading of $\mathrm{P}$ have changed since the mid-1990s, with an earlier and larger mass of $\mathrm{P}$ released from the sediments each summer. Catchment inputs of total oxidised N (NOx) decreased from the peak value of 10,186T/yr in 1995 to 5,396T/yr in 2011, coinciding with a reduction in lake water concentrations. External inputs and lake concentrations of NOx were highly correlated $(\mathrm{R}=0.88)$. Water temperature increased approximately $1 \mathrm{C}$ and was a predictor of variation in chl- $a$ from 1974 to 2012. After the peak chl-a concentration in 1993, dissolved inorganic N (DIN) also became an important predictor, accounting for almost half of the 44\% variance explained by a hierarchical partition model. Decreasing log (DIN:TP) ratios suggest that $\mathrm{N}$ limitation of chl- $a$ has become more important in the lake recently.
\end{abstract}

\section{INTRODUCTION}

Cultural eutrophication remains a major threat to freshwater systems globally (Wurtsbaugh et al. 2019) and over-enrichment of lakes can lead to undesirable effects on water quality such as elevated concentrations of chlorophyll and anoxic conditions. Climate-induced water temperature increases have also had considerable impacts on the functioning of shallow lakes (Carvalho and Kirika 2003) impacting chemical, physical and biological processes (Pettersson et al. 2003; Köhler et al. 2005). Water quality across Europe continues to decline (European Environment Agency 2018) despite management meaures aimed to improve ecological status implemented under the European Water Framework Directive (WFD) (European Commission 2000). Many of the management measures focus on nutrient control, however, after any reduction of nutrient inputs from the catchment, water quality improvements can be impeded due to the release of P from the lake sediment (Phillips et al. 1994; Søndergaard et al. 2013). While lakes can respond well to reductions in $\mathrm{N}$ loading (e.g. Shatwell and
Köhler 2019) internal P regeneration may act as a considerable source of P (Nürnberg 1987), especially in eutrophic lakes (Søndergaard et al. 1999) such as Lough Neagh in Northern Ireland (Gibson et al. 2001). Internal release of $\mathrm{P}$ is enhanced by factors such as increasing temperature, decreasing nitrate concentrations and increasing $\mathrm{pH}$ (Jensen and Andersen 1992) and it can impact the stoichiometric composition of lake water chemistry, influencing primary production limitation (Ding et al. 2018). Though it is widely acknowledged that $\mathrm{P}$ frequently limits primary production, $\mathrm{N}$ can be also limiting in eutrophic lakes, especially where $\mathrm{N}$ fixing phytoplankton do not compensate for low N availability (Shatwell and Köhler 2019). Lough Neagh is well studied and has had numerous catchment measures implemented since the 1980s, including the upgrade of sewage treatment works and catchment-wide controls on diffuse pollution from agricultural sources. Despite these measures, the 2020 WFD TP status was Bad $(139 \mu \mathrm{g} / \mathrm{L})$ and well exceeded the upper threshold that is compatible with Good Ecological Potential (24ug/L). Current targets aim to lower the TP concentration 
to between $49 \mathrm{ug} / \mathrm{L}$ and $97 \mathrm{ug} / \mathrm{L}$, which is the range for the Poor status category; these targets take no account of internally released P. In order to set realistic water quality objectives, it is important to understand the characteristics of both internal and external nutrient loading as well as trends in nutrient concentrations and primary production.

We used long-term monitoring results for Lough Neagh to describe how water concentrations of nutrients have changed in response to both external and internal nutrient inputs. The main dataset was from 1974-2012 but some variables had values to 2016. We described long-term trends in lake water $\mathrm{P}, \mathrm{N}$ and temperature and their influence on chlorophyll-a (chl-a) over the period (1974-2012) and before and after peak chl-a concentrations in 1993. We explored $\mathrm{N}$ and P loading trends from the catchment (1984-2011) and P internal load (mass balance trends: annual 1984-2013 and summer 1984-2014). Trends in the volume of river water inflow were investigated and the correlation of lake water nutrient concentrations with the mass of external loading was calculated. We investigated the timing of lake water nitrate depletion and the magnitude of subsequent $\mathrm{P}$ remobilisation from lake sediment. We also investigated changes in chl-a:TP ratios, lake water chemistry stoichiometry and potential $\mathrm{N}$ limitation of primary production.

\section{MATERIALS AND METHODS}

\section{STUDY SITE}

Lough Neagh has an area of $383 \mathrm{~km}^{2}$ and volume of $3.45 \times 10^{9} \mathrm{~m}^{3}$. It is shallow, hypereutrophic and polymictic with a mean and maximum depth of $8.9 \mathrm{~m}$ and $34 \mathrm{~m}$, respectively. A full description of the lake is given in Wood and Smith (1993).

\section{WATER SAMPLING AND ANALYSES}

Integrated water samples were collected at a midlake station in 10m water depth weekly (1974-92) or fortnightly (1993 to present). The sampling location was representative of overall lake water chemistry conditions (Gibson et al. 2000). Chl-a was determined according to Talling and Driver (1963). Total P (TP) and soluble reactive P (SRP) were measured according to Eisenreich et al. (1975) and Murphy and Riley (1962), respectively. Filtered samples $(0.45 \mu \mathrm{m})$ were used to determine total oxidised nitrogen (NOx, the sum of nitrate and nitrite) and ammonium based on Chapman et al. (1967). Dissolved inorganic nitrogen (DIN) was the sum of NOx and ammonium. Total Kjeldahl N (TKN) was determined on unfiltered samples (Stevens 1976). Total N (TN) was the sum of NOx and TKN. Water temperature was recorded at $10 \mathrm{~m}$, which was taken as representative of the water column temperature given that the mean depth is $8.9 \mathrm{~m}$.

\section{LAKE NUTRIENT LOADING AND SEDIMENT RELEASE}

The loadings of TN, NOx and TP to Lough Neagh were estimated using results from the eight major inflowing rivers, (daily river flow data, available from 1984-2011) and nutrient concentrations in the rivers from water samples collected weekly. The river nutrient concentration and flow results were used to calculate the loadings for each year using flow weighted means and interpolation (Johnes 2007).

As the monitored catchments represented 86\% of the Lough Neagh catchment, the nutrient load to the lake (1984-2011) was estimated using a conversion factor (Smith 1993) and by dividing the sum of the loads from the monitored catchments by 0.86 . If $>4 \%$ of flow data for a year was missing, then nutrient load for that year was not derived. The nutrient and flow data for the outflow were used to calculate the lake nutrient output. The mass of $\mathrm{P}$ released from the sediment was estimated using: (whole lake P mass at end of time period whole lake P mass at beginning of time period) (P mass input - $\mathrm{P}$ mass output).

The trends of water column $\mathrm{N}$ depletion and release of sediment $\mathrm{P}$ were determined. The month within which the NOx concentration fell below $0.06 \mathrm{mg} / \mathrm{L}$ was identified; Gibson et al. (1992) found that the summer (July-September) average nitrate concentration fell from 0.20 to $<0.05 \mathrm{mg} / \mathrm{L}$ over the 1971 to 1980 period, so $0.06 \mathrm{mg} / \mathrm{L}$ was chosen as a threshold for the depletion of NOx through assimilation by phytoplankton. We also identified the month that the SRP concentration began to increase above $0.010 \mathrm{mg} / \mathrm{L}$ (where the previous month was below this value) and this was the threshold used to indicate the start of sediment $\mathrm{P}$ release as described by Gibson and Stewart (1993). Lake water concentration results were available weekly up to 1992 , but fortnightly thereafter. We could not identify these times more precisely than monthly for the whole 1974-2012 period.

\section{STATISTICAL ANALYSES}

The measurements for water temperature and the concentrations of chl-a, SRP, TP and NOx in Lough Neagh water, at weekly intervals from 1974 to 1992-and fortnightly up to 2012-were used to calculate monthly mean values. The long-term trends and seasonality were then investigated using generalised additive models (GAMs).

The additive model for each variable fitted a smooth function to describe the long-term trend and a smooth function to describe the average seasonal pattern (Equation 1). 


$$
\begin{aligned}
\mathrm{y}= & \beta_{0}+\mathrm{f}_{1}(\text { year })+\mathrm{f}_{2}(\text { doy })+\varepsilon, \varepsilon \sim \mathrm{N}\left(0, \mathrm{~V} \sigma^{2}\right), \\
& \mathrm{V} \sim \mathrm{AR}(1)
\end{aligned}
$$

Where $\beta_{0}$ is the overall mean and $\mathrm{f}()$ is a smooth function; cubic regression splines were used for the long-term trend (year) with cyclic cubic regression splines for the seasonal pattern (doy, day of year). The monthly mean concentrations were transformed using natural logs. As some of the SRP and NOx values were below the limits of detection (LODs), they were treated as censored observations. The ROS method (Helsel 2005) was applied using the NADA package in R (Lee 2013; R Development Core Team 2014) to impute such values to take account of these LODs. The mgcv library in $\mathrm{R}$ ( $\mathrm{R}$ Development Core Team 2014; Wood 2017) was used to fit the GAMs (Hastie and Tibshirani 1990). The function gamm in $\mathrm{mgcv}$ was used to incorporate an autocorrelated error structure (order 1) into the model fitting. Figures generated from the additive models displayed the estimated smoothed nonparametric regression line for each covariate effect for the long-term trend and seasonal pattern (i.e., year and day of year, respectively) with shaded 'variability' bands to illustrate \pm 2 standard errors (SEs). Covariates were expressed as deviation from their mean of the time series.

The trends in N:P ratios and catchment nutrient loading were described using nonparametric regression models. The sm.regression function in the sm library in R (Bowman and Azzalini 2014) was applied to the log of mean annual nutrient ratios and annual catchment nutrient loading in order to fit smooth nonparametric long-term trends (e.g. Ferguson et al. 2008).

The functions for the GAMs and the nonparametric regressions provide inferences on the significance of the nonparametric effects through approximate tests, such as approximate F-tests (Hastie and Tibshirani 1990). Mann-Kendall (MK) tests were used to describe the direction of any changes in the variables. Hierarchical partitioning (HP) (Chevan and Sutherland 1991) investigates all multiple regression models jointly in order to find the most likely causal factors (MacNally 2002) and was used here to uncover the relationship between chl-a, DIN, TP and water temperature. This technique uncovers the tested predictor variables with the most explanatory power in relation to chl-a. Hierarchical partitioning calculates the independent effects (distinct from partial correlation) of each explanatory variable and is an effective method for variables that may be collinear as it dampens the effects of multicollinearity (MacNally 1996). For a set of predictor variables, HP averages the effect of each parameter on goodness of fit measures, in our case $\mathrm{R}^{2}$, across all possible $2^{\mathrm{K}}$ models, for $\mathrm{K}$ predictor variables (MacNally 2002). This allows the explanatory effect of each parameter to be separated into an independent effect and a joint effect in common with the other variables. The method can provide insight into potential explanatory relationships. For each of our tested variables, the independent and joint effects are presented as a percent of the total variance explained (MacNally 2000). Hierarchical partitioning (HP) and associated randomisation tests analyses were completed using the hier.part package (Walsh and MacNally 2013) in R. Preliminary pairwise plots (Appendix I) showed linearity between chl-a, the nutrients and water temperature demonstrating suitability for the HP method.

\section{RESULTS}

\section{CATCHMENT LOADING AND LAKE WATER CONCENTRATION OF N AND P}

Total $\mathrm{N}$ from the catchment was strongly correlated with catchment NOx load; $R^{2}=0.85, P<0.001, \mathrm{n}=16$, and so NOx was used as an indicator of TN as TKN data were unavailable since 2002. For the data available for TN river loading (1984-2002, three missing years), NOx made up a mean of $66 \%(\mathrm{SD}=6 \%)$ of the TN; similar to the value of $64 \%$ found by Gibson et al. (1992). Total oxidised N loading to Lough Neagh from the catchment (1984-2011) demonstrated a significant trend (nonparametric regression $P<0.05$; Fig. 1a; Table 1); the load generally increased from 1984 until a peak value of 10,186T/yr was reached in 1995, then decreased to 5,396T/yr at the end of the time series. Mean TP loading from the catchment was 606T/yr from 1984 to 2011; catchment inputs were variable from year to year and no significant trend was evident (Fig. 1b; Table 1). Trends in the volume of river inflow were not apparent.

The long-term GAM of the log of lake NOx (Fig. 2a; $P<0.001$; Table 1) revealed decreasing concentrations after the mid-1990s peak $(0.83 \mathrm{mg} / \mathrm{L}$ in 1996) until the end of the data sequence $(0.33 \mathrm{mg} / \mathrm{L}$ in 2012). A significant decrease in concentration was evident after the mid-1990s (MK $P<0.01$ ) but no significant trend before this. The annual seasonal cycle of lake water NOx (Fig. 2b) was identical to that found by Gibson et al. (1992) using results for the 1975 to 1987 period, showing assimilation by phytoplankton, which reduced the concentration (lowest by June) followed by mineralisation, which increased it.

The log of lake water TP concentration (GAM $P<0.001$; Fig. 3a; Table 1), showed a generally increasing trend from 1974 to 2012 (MK $P<0.001$ ). Peak mean annual TP concentration, $164 \mu \mathrm{g} / \mathrm{L}$, was reached in 1997 and concentrations remained high thereafter. A spring lake water TP minimum similar to that described by Gibson and Stewart (1993) was evident (Fig. 3b). The log of lake water SRP concentration (GAM $P<0.001$; Fig. 3c; Table 1), also 
showed a general increasing trend over the 1974 to 2012 period (MK $P<0.001$ ). Soluble reactive $\mathrm{P}$ has gradually increased since the early 1990s. Peak lake water SRP concentration occurred in 2005
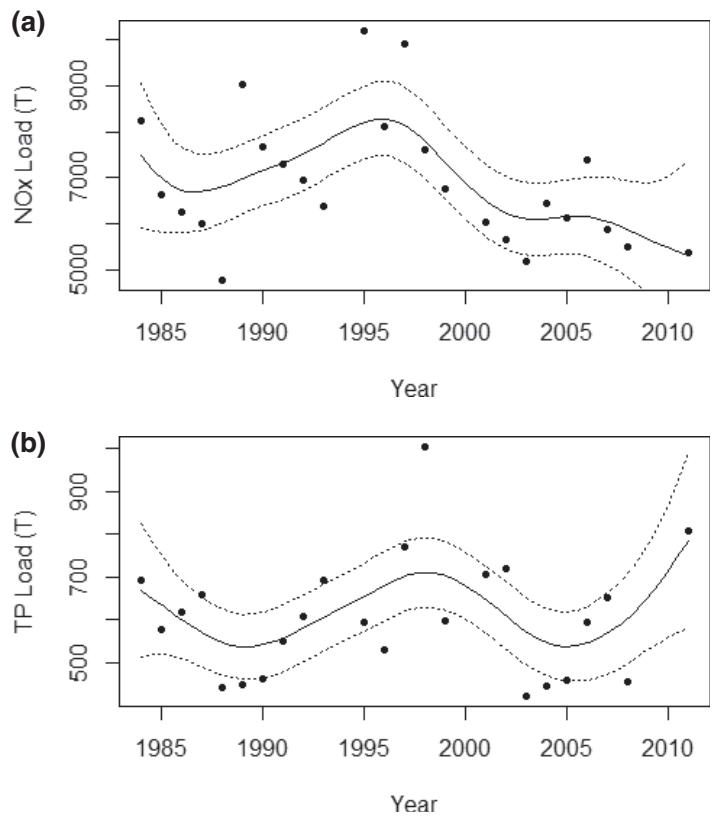

Fig. 1-Nonparametric regression of total oxidised nitrogen (NOx) (a) and total P (TP) (b) loading from the Lough Neagh catchment in tonnes $(T), 1984-2011$.
$(92 \mu \mathrm{g} / \mathrm{L})$ and remained relatively high until the end of the data series; 2012 mean concentration was $72 \mu \mathrm{g} / \mathrm{L}$. A spring lake water SRP minimum was also evident (Fig. 3d).

The catchment loading of NOx and the lake concentrations of NOx (1984-2011) were positively correlated $(R=0.88 ; P<0.001$; Fig. $4 a)$. Lake water concentrations of the nutrient decreased in line with falling inputs over the time series. In contrast, TP input from the catchment and lake concentration of TP (1984-2011) were not correlated $(R=0.25$; $P>0.05$; Fig. $4 \mathrm{~b})$ and showed no trend. The increasing lake TP concentration was not reflected by the catchment input of TP, which showed no significant trend in direction.

\section{INTERNAL LOADING OF P}

The annual (1984-2013) and summer (1984-2014) lake water nutrient mass balances were estimated for TP. Significant changes were not evident at the annual scale, however, increases in the summer mass of sediment TP release have occurred (MK $P$ $<0.05)$. A change in the magnitude of release has occurred, commencing in the 1990s. From 1984 to 1994 the mean summer release ofTP was 107T, and from 1996 to 2014 the mean TP release increased to $249 \mathrm{~T}$ (Fig. 5). The detailed monthly analysis of NOx and SRP (Fig. 6) showed that lake water NOx was depleted earlier on in the year and, subsequently, SRP was released from the sediment, indicated by a sudden rise in the lake water SRP concentration.

Table 1-Smoothed regression models ( $\mathrm{Sm} \mathrm{Reg}$ ) for the catchment input of total oxidised $\mathrm{N}$ (C_NOx, T/yr), catchment input of total P (C_TP, T/yr) and the log ratio of dissolved inorganic $\mathrm{N}$ and total $\mathrm{P}$ (DIN:TP). Generalised additive models (GAM) for log total oxidised $\mathbf{N}$ (NOx, $\mathrm{mg} / \mathrm{L}), \log \mathrm{TP}(\mathrm{TP}, \mu \mathrm{g} / \mathrm{L}), \log$ soluble reactive $\mathrm{P}(\mathrm{SRP}, \mu \mathrm{g} / \mathrm{L})$, water temperature at $10 \mathrm{~m}$ depth (Temp $10 \mathrm{~m}, \mathrm{C})$ and $\log$ chlorophyll- $a,(\mathrm{Chl}-a, \mu \mathrm{g} / \mathrm{L})$. Direction of trends over tested time periods provided by Mann Kendall tests (MK). $P<0.05 \star, P<0.01 \star \star, P<0.001 \star \star \star$. NS is not significant.

\begin{tabular}{|c|c|c|c|c|c|}
\hline \multicolumn{2}{|c|}{ Model and time period } & \multirow{2}{*}{$\frac{\text { Variable }}{\text { C_NOx }}$} & \multirow{2}{*}{$\frac{\text { Significance }}{\star}$} & \multicolumn{2}{|c|}{ Trend $(M K)$ and time period } \\
\hline \multirow[t]{2}{*}{ Sm Reg } & 1984-2011 & & & Decreasing * & $1984-2011$ \\
\hline & & C_TP & NS & NS & $1984-2011$ \\
\hline Sm Reg & $1974-2016$ & DIN:TP & $\star \star$ & Decreasing $\star \star \star$ & $1974-2016$ \\
\hline \multirow[t]{11}{*}{ GAM } & $1974-2012$ & $\mathrm{NOx}$ & $\star \star \star$ & NS & $1974-2012$ \\
\hline & & & & NS & $1974-1996$ \\
\hline & & & & Decreasing $\star \star$ & $1997-2012$ \\
\hline & & $\mathrm{TP}$ & $\star \star \star$ & Increasing $\star \star \star$ & $1974-2012$ \\
\hline & & SRP & $\star \star \star$ & Increasing $\star \star \star$ & $1974-2012$ \\
\hline & & Temp $10 \mathrm{~m}$ & $\star \star \star$ & Increasing $\star \star \star$ & $1974-2012$ \\
\hline & & & & NS & $1974-1995$ \\
\hline & & & & Increasing $\star$ & $1996-2012$ \\
\hline & & Chl- $a$ & $\star \star \star$ & NS & $1974-2012$ \\
\hline & & & & Increasing $\star \star \star$ & $1974-1993$ \\
\hline & & & & Decreasing $\star \star \star$ & $1994-2012$ \\
\hline
\end{tabular}




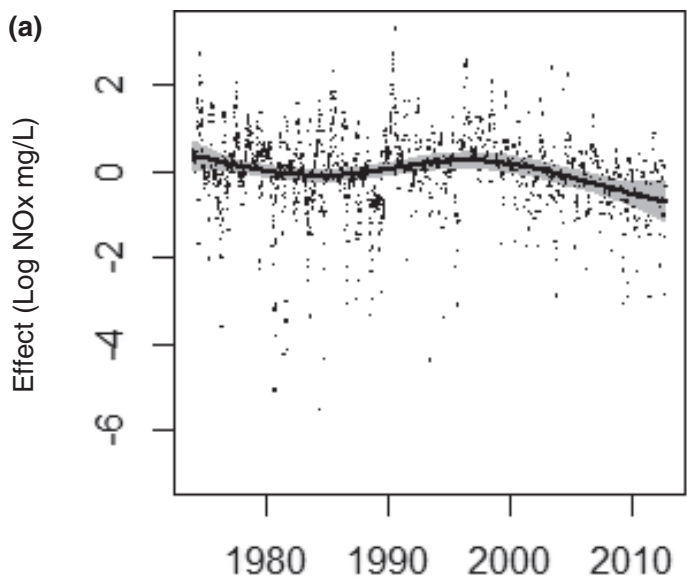

year

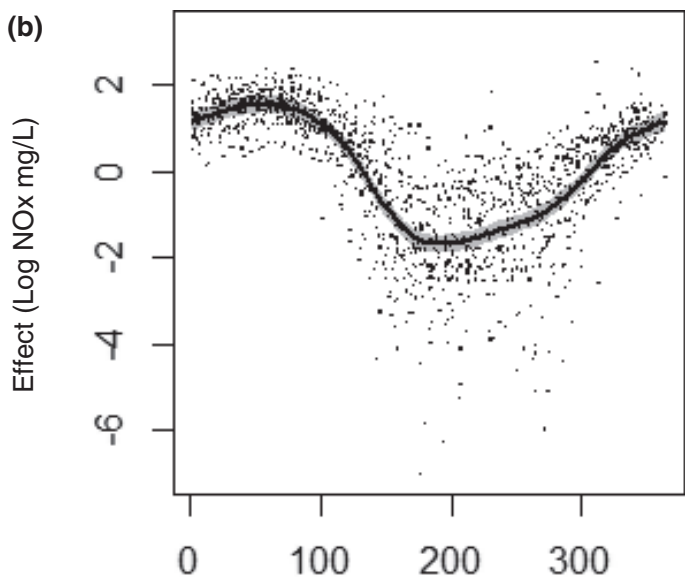

day of year

Fig. 2-Long-term trend (a) and average seasonal pattern (b) for log total oxidised nitrogen $(\log \mathrm{NOx}, \mathrm{mg} / \mathrm{L})$ concentration from Jan 1974 to Dec 2012 as responses in additive nonparametric models. The shaded region identifies $\pm 2 \mathrm{SE}$ from the estimate and points are the partial residuals for each covariate respectively (indicating e.g., the remaining long-term trend and variation after fitting the smooth seasonal pattern and vice versa).

This commenced earlier as the time series progressed (1984-2012), from about June rather than July (Fig. 6).

\section{LAKE WATER STOICHIOMETRY, WATER COLUMN TEMPERATURE AND CHL-A,}

The log of the annual average mass ratio of DIN:TP has decreased significantly over the time series (1974-2016), nonparametric reg. $P<0.01$; MK $P$ $<0.001$ (Table 1), especially since the mid-1990s (Fig. 7). The mean log (DIN:TP) ratio was 1.43 before chl- $a$ peak concentration in 1993 and was 1.08 afterwards; ratio values were lower and less variable after the mid-1990s (Fig. 7).

Water temperature at 10m (1974-2012) showed a significant increasing trend (GAM and $\mathrm{MK}$ $P<0.001$; Table 1). The increase was more rapid and significant after the mid-1990s (MK $P<0.05$ after 1995 and >0.05 before; Table 1); the increasing pattern of water temperature over the time series was driven by the increasing values after the mid-1990s (Fig. 8). Mean annual water temperature $(10 \mathrm{~m})$ for 1974-95 was $9.88 \mathrm{C}$, increasing to $10.61 \mathrm{C}$ afterwards (1996-2012).

Nonparametric trends were evident in the $\log$ of chl-a concentrations (GAM $P<0.001$; Fig. 9a; Table 1); values increased from 1974 until the peak of $75 \mu \mathrm{g} / \mathrm{L}$ (1993), then decreased to $44 \mu \mathrm{g} / \mathrm{L}$ in 2012. Monotonic trends in chl-a concentrations were not apparent over the entire time but a significant increase was evident up to the peak in 1993 (MK $P<0.001)$ and a decrease was evident after 1993 (MK $P<0.001$; Table 1). Seasonal variation in chl- $a$ was also present (Fig. 9b); the modeled concentration was high for much of the year, from March to October, with a peak in April-May and a small increase in August-September. By testing all possible multiple regression models for the $\log$ of annual mean chl-a concentration through HP we found that for the three predictor variables tested: mean annual water temperature at $10 \mathrm{~m}$, $\log$ of mean annual DIN and TP, $13 \%$ of variation was explained (1974-2012). Water temperature was identified as the most important variable and had the strongest effect on chl-a (HP randomisation test $P<0.05 ; 1974-2012)$ out of the three predictor variables, accounting for $77 \%$ of the explained variation (Table 2). We also investigated the influence of the three variables before and after the chl- $a$ peak in 1993. During the period of increasing chl-a concentrations the model for log chl-a was very weak (HP R $\left.{ }^{2}<0.01,1974-93\right)$. A large change, however, was apparent after 1993 when concentrations of chl- $a$ decreased, HP showed that the three predictor variables accounted for $44 \%$ of variation in log chl-a concentration (1994-2012). Log DIN concentration and water temperature independent effects accounted for $46 \%$ and $47 \%$ of variation explained, respectively, (Table 2); both were significant (randomisation test $P<0.05$ ). Dissolved inorganic $\mathrm{N}$ was positively associated with chl- $a$ and temperature was negatively associated (Appendix I, b and c, respectively). The $\log (x+1)$ of the annual average ratio of chl-a:TP generally decreased after the peak chl-a concentration 1993, and remained relatively low until the end of the data series (Appendix II). 


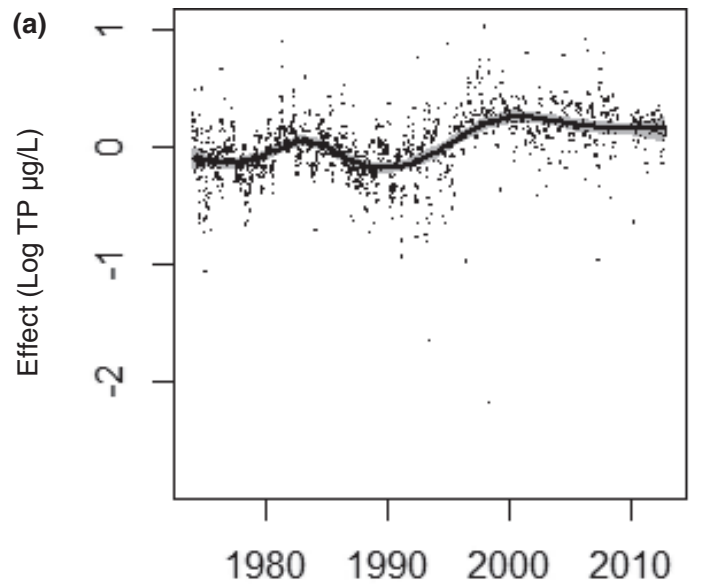

year

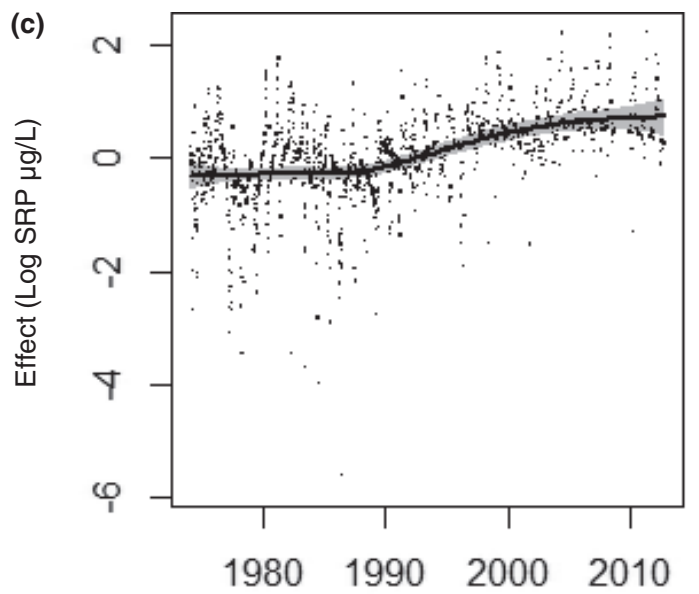

year

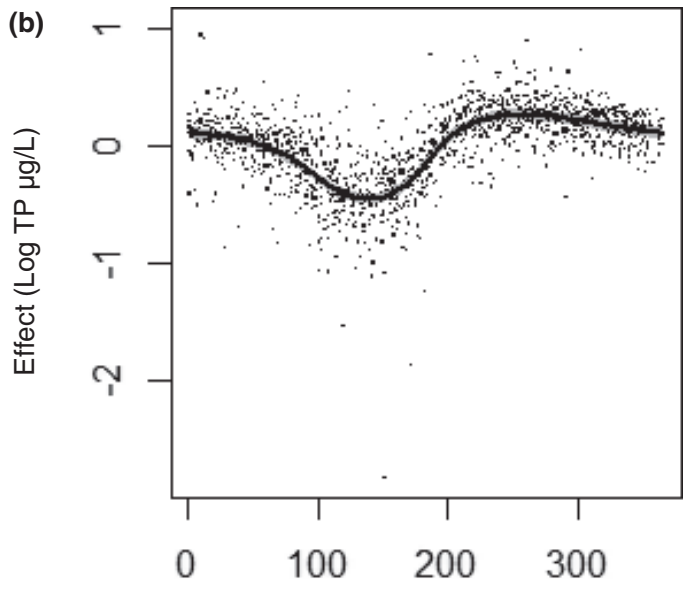

day of year

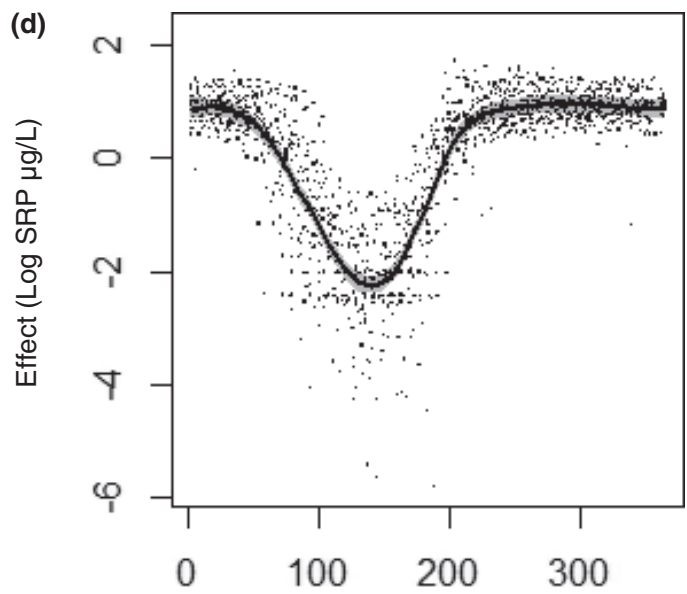

day of year

Fig. 3-Long-term trend and average seasonal pattern for $\log$ total phosphorus $(\log \mathrm{TP}, \mu \mathrm{g} / \mathrm{L}$; $a$ and $b$ respectively), and $\log$ soluble reactive phosphorus ( $\log \mathrm{SRP}, \mu \mathrm{g} / \mathrm{L}$; c and d) Jan 1974 to Dec 2012 as responses in additive nonparametric models. The shaded region identifies $\pm 2 \mathrm{SE}$ from the estimate and points are the partial residuals for each covariate respectively (indicating e.g., the remaining long-term trend and variation after fitting the smooth seasonal pattern and vice versa).

\section{DISCUSSION}

THE INPUT OF NUTRIENTS AND THE LAKE WATER CONCENTRATION OF NUTRIENTS

The considerable length of the dataset allowed us to reveal trends in water chemistry and show that lake water quality variables underwent significant change after the mid-1990s. We showed that water concentration of NOx was closely correlated with catchment loading (Fig 4a) indicating that the lake was responding to decreased $\mathrm{N}$ loading from the catchment, which was apparent after the mid-1990s. The poor correlation between catchment inputs of
$\mathrm{P}$ and lake water concentrations (Fig. 4b) and results of the lake P mass balance (Fig. 5) indicate that lake water $\mathrm{P}$ dynamics are dominated by in-lake processes instead of catchment inputs. The increasing values of lake TP (Fig. 3a) are likely to be driven by the SRP concentration increase in the Lough (Fig. 3c). A very similar lake water nutrient response to reduced $\mathrm{N}$ and $\mathrm{P}$ loads in a eutrophic lake is described by Köhler et al. (2005). Internal loading from $\mathrm{P}$ has been identified as one of the reasons why many eutrophic lakes do not respond well to lake water quality restoration efforts (Søndergaard et al. 2007) and Lough Neagh with its increasing 
(a)

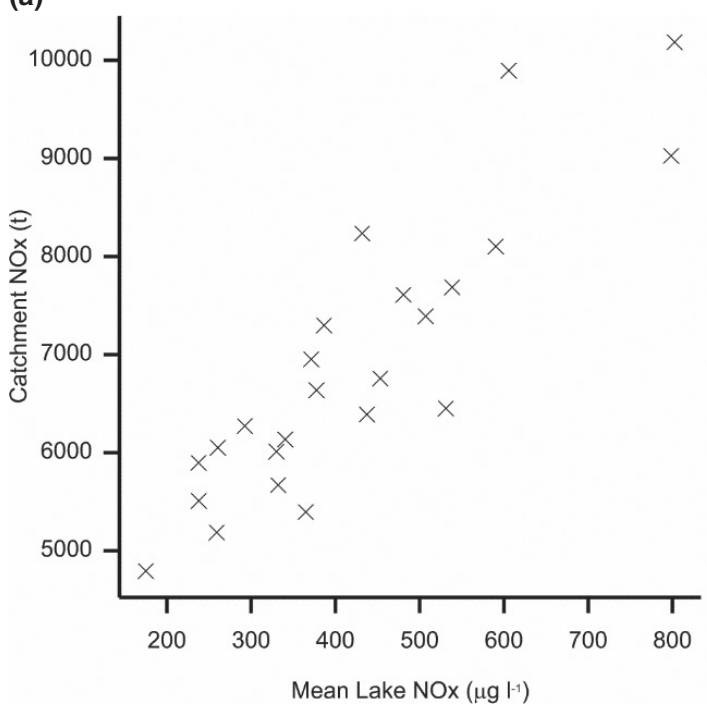

(b)

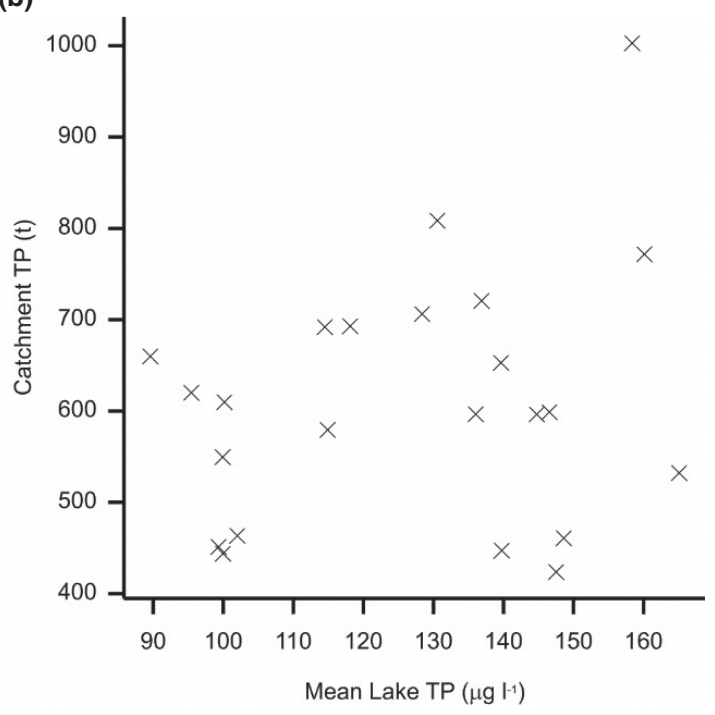

Fig. 4-Annual mean lake water concentration for total oxidised nitrogen $(\mathrm{NOx} ; \mu \mathrm{g} / \mathrm{L})$ and catchment loading of NOx tonnes (T) per year (a) and annual mean lake water concentration for total P (TP; $\mu \mathrm{g} / \mathrm{L})$ and catchment loading of TP (T) per year (b).

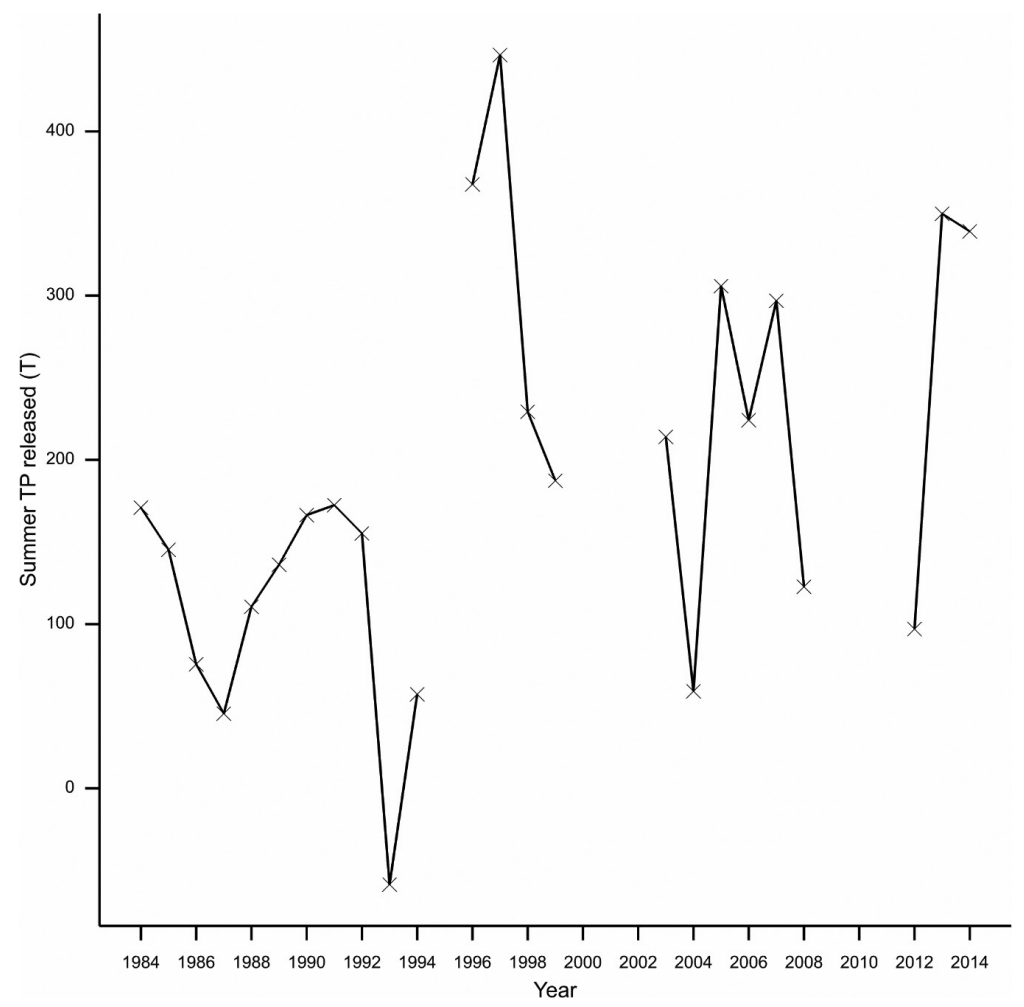

Fig. 5-Net release of total P (T) for summer (June, July, August) 1984-2014.

mass of summer $\mathrm{P}$ release is experiencing the negative impacts of internal loading. The greatest mass of internal P in Lough Neagh is released in the summer when higher temperatures and low oxygen conditions accelerate $\mathrm{P}$ release (Gibson et al. 2001); coinciding with the most biologically active time in northern temperate lakes. Our observed earlier start to $\mathrm{P}$ release in the summer is likely contributing to this greater mass of $\mathrm{P}$ released. The average annual cycles of NOx (Fig. 2b), P (Fig. 3b and 3d) and chl-a 


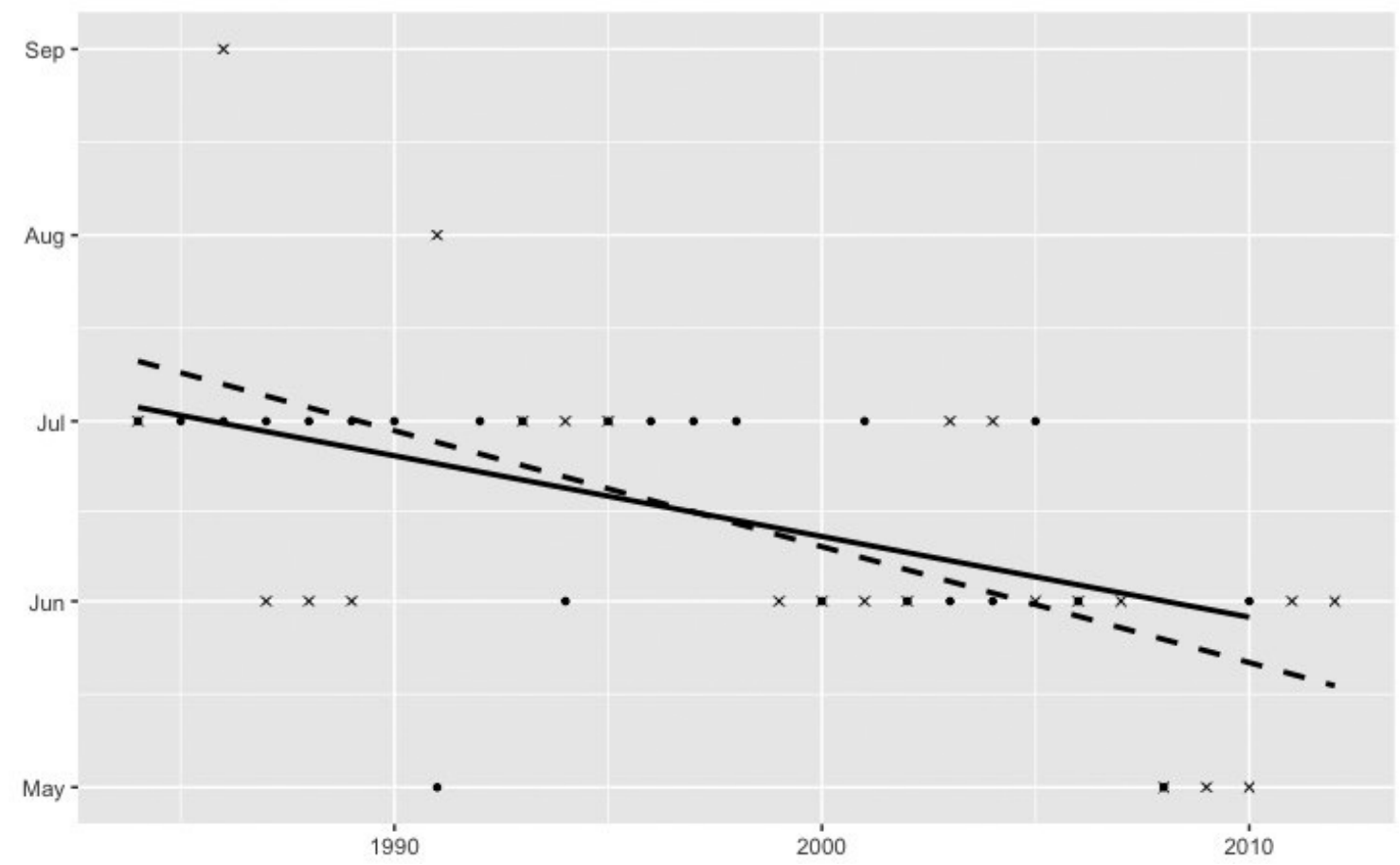

Fig 6-Temporal trends in commencement of total oxidised N (NOx) depletion (concentration of $\mathrm{NOx}<0.06 \mathrm{mg} / \mathrm{L})$ and soluble reactive $\mathrm{P}$ (SRP) sediment release (concentration of SRP was $>10 \mu \mathrm{g} / \mathrm{L}), 1984-2012$. The temporal trend of NOx is represented by dots and the solid line, while that of SRP is represented by crosses and the dashed line.

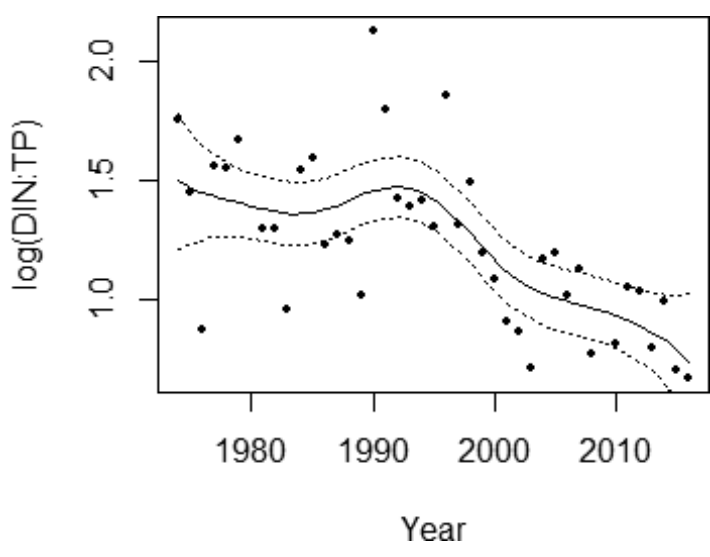

Fig. 7-Log of mean annual mass ratio of dissolved inorganic $\mathbf{N}$ (DIN) and total $\mathbf{P}$ (TP) in Lough Neagh 1974-2016, $n=41$.

(Fig. 9b), were similar to well-established patterns (Gibson 1993; Gibson and Stewart 1993). However, our more detailed analysis of the $\mathrm{N}$ and $\mathrm{P}$ seasonal cycles in Lough Neagh (Fig. 6) showed that there have been changes in the time of year that NOx was depleted through assimilation by phytoplankton and in the start and mass of $\mathrm{P}$ released from the sediment. Iron compounds have an important role in binding $\mathrm{P}$ in the sediments of Lough Neagh as there is very little calcium carbonate in the sediment (Rippey 1980; Fletcher 1980). This means that iron mediated release of $\mathrm{P}$ (Davison 1993) is the major release mechanism, and this can occur in sediments that are not completely anoxic (McKean 1986; Moore and Reddy 1994; Smith et al. 2011). Elevated lake water nitrate concentrations help maintain a high redox potential at the sediment interface, keeping the iron bound P fixed (Jensen and Andersen 1992). Release of $\mathrm{P}$ from the lake sediment after the depletion of nitrate in the summer has been previously described in Lough Neagh (Gibson et al. 2001), however key changes have been observed since then in this study, specifically earlier annual depletion of NOx from the water column and subsequent release of $\mathrm{P}$ from the sediment (Fig. 6). We also noted an increase in the average mass of P released (1984-2014) (Fig. 5). Our results show that these changes were established by 2000 . Factors such as the observed decreasing nitrate and increasing water temperature have been shown to enhance SRP release from eutrophic lake sediment (Jensen and Andersen 1992). The observed increase in water column temperature in Lough Neagh will likely further impact release. This means that the effectiveness of $\mathrm{P}$ control measures in the catchment, with the aim of reducing lake $\mathrm{P}$ will be limited. Internal loading inputs are considerable in large lakes such as Lough Neagh where intensive use of catchment land have resulted in a large mass 


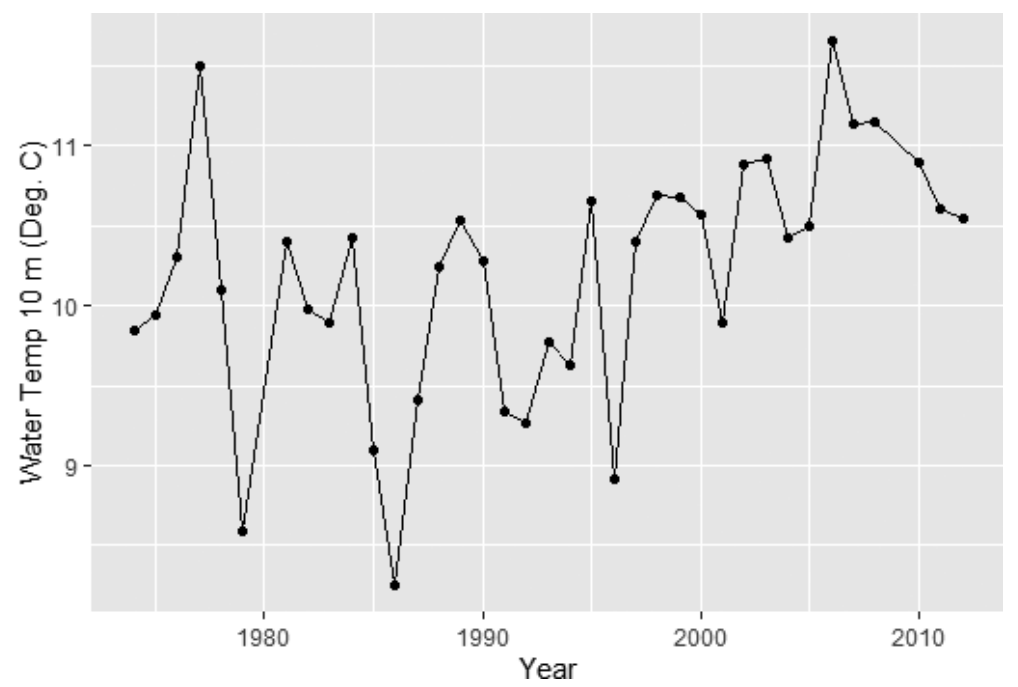

Fig. 8-Mean annual water temperature at 10m (C), 1974-2012.

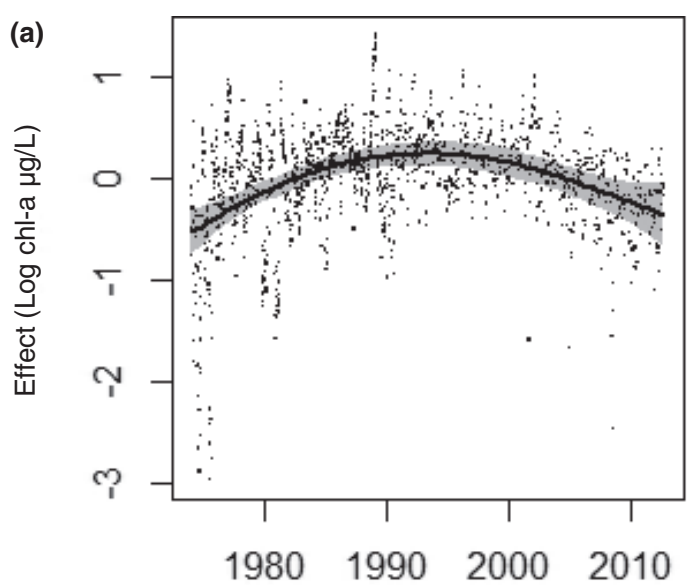

year

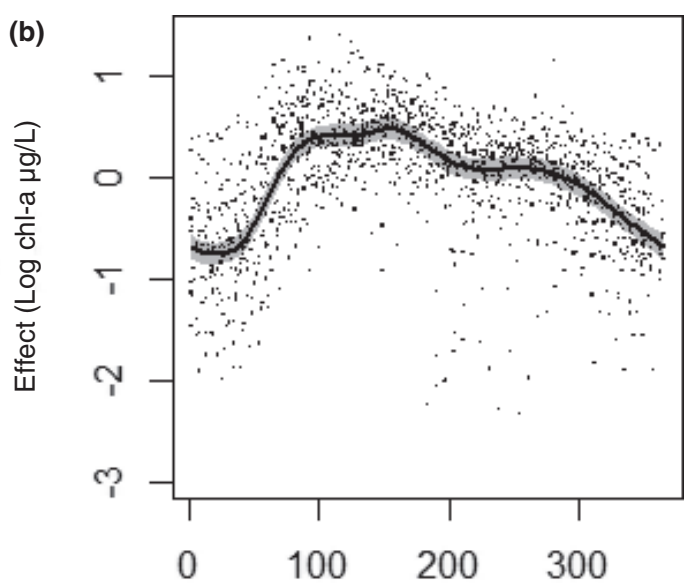

day of year

Fig. 9-Long-term trend (a) and average seasonal pattern (b) for log chlorophyll-a concentration $(\log \mathrm{chl}-\mathrm{a}, \mu \mathrm{g} / \mathrm{L})$ from Jan 1974 to Dec 2012 as responses in additive nonparametric models. The shaded region identifies $\pm 2 \mathrm{SE}$ from the estimate and points are the partial residuals for each covariate respectively (indicating e.g., the remaining long-term trend and variation after fitting the smooth seasonal pattern and vice versa).

of $\mathrm{P}$, deposited over many years, in the lake sediment (Søndergaard et al. 1999).

\section{WATER CHEMISTRY STOICHIOMETRY,WATER COLUMN TEMPERATURE AND CHL-A}

Nitrogen and $\mathrm{P}$ are two of the most important nutrients in primary production and lake water stoichiometry determines nutrient limitation (Redfield 1958). Knowing the ratios of the most available form of these nutrients in hypereutrophic lakes can help with predicting biological quality.
Dissolved inorganic N: total P (DIN:TP) ratios are commonly used as indicators of $\mathrm{N}$ and $\mathrm{P}$ limitation in phytoplankton (Bergström 2010; Ptacnik et al. 2010). Log transformed ratios are more appropriate to use in ecological stoichiometry as transformation helps to avoid errors such as bias towards P limitation (Isles 2020). Mass DIN:TP ratios less than 2.6 can indicate $\mathrm{N}$ limitation (Kolzau et al. 2014); the natural $\log$ of 2.6 is 0.96 . In Lough Neagh log mean annual ratios have been below 0.96 more frequently since 2001, than any time period previously recorded (Fig. 7) indicating 
Table 2.- Hierarchical partitioning of the variables in chlorophyll- $a$ (chl- $a$ ) regression models, showing the independent and joint contributions of each variable to the explained variance in the log of annual mean chl- $a$. DIN - log of annual mean dissolved inorganic N,TP - log of annual mean total $P$, Water temp - annual mean water temperature at $10 \mathrm{~m}$. Randomisation test $P<0.05 \star$.

\begin{tabular}{|c|c|c|c|c|}
\hline Time period & Parameter & $\begin{array}{c}\text { Independent } \\
\text { contribution to } r^{2}\end{array}$ & $\begin{array}{c}\text { Joint contribution } \\
\text { to } r^{2}\end{array}$ & $\begin{array}{c}\text { Independent } / r^{2} \\
(\%)\end{array}$ \\
\hline \multirow{4}{*}{$1974-2012$} & DIN $(\log )$ & 0.012 & 0.010 & 9.064 \\
\hline & Water temp* & 0.102 & -0.010 & 77.100 \\
\hline & TP (log) & 0.018 & -0.017 & 13.836 \\
\hline & Total & 0.133 & -0.017 & 100.000 \\
\hline \multirow{4}{*}{$1994-2012$} & DIN $(\log )^{\star}$ & 0.204 & 0.147 & 46.322 \\
\hline & Water temp^ & 0.205 & 0.102 & 46.678 \\
\hline & TP $(\log )$ & 0.031 & 0.001 & 7.000 \\
\hline & Total & 0.440 & 0.249 & 100.000 \\
\hline
\end{tabular}

increased $\mathrm{N}$ limitation in recent years. The observed decrease in $\log$ (DIN:TP) was influenced by the decrease in lake water $\mathrm{N}$ and increase in lake $\mathrm{P}$ brought about by $\mathrm{P}$ remobilisation from the sediments. Low concentrations of bioavailable $\mathrm{N}$ can limit phytoplankton over the long term, even with high concentrations of available P (Shatwell and Köhler 2019). The role of $\mathrm{N}$ can become more important in controlling primary production after nutrient reduction in some shallow lakes (Moss et al. 2005). Ratios of chl-a:TP have been used to provide information on potential $\mathrm{P}$ limitation (Spears et al. 2013) and in Lough Neagh the generally declining values of $\log ((\mathrm{chl}-a: \mathrm{TP})+1)$ since 1993 to the end of the data series indicate that factors other than $\mathrm{P}$ are limiting primary production by phytoplankton.

Of the variables tested in HP, temperature was identified as the only significant predictor of chl-a over the entire time series (Table 2). This negative association may be linked to zooplankton predation of phytoplankton over the entire time series. Fitzsimons and Andrews (1993) showed that zooplankton grazing was an important factor in regulating phytoplankton abundance and that temperature likely played an important role in zooplankton population density in the late 1970s. However after 1993 a large change occurred in the relationship between chl$a$, nutrients and water temperature; DIN became a significant predictor of chl-a, further supporting the case of increased $\mathrm{N}$ limitation after the mid-1990s. Hierarchical partitioning also identified water temperature as having a large independent effect on chl-a, after the peak value in 1993, similar in magnitude to the effect of DIN, this relatively large influence of temperature may be linked to temperature driven phenological changes in zooplankton, which have been shown to directly impact phytoplankton biomass through increased predation (Gerten and Adrian 2000). Air temperature was found to be the most important variable explaining zooplankton biomass and abundance by (Cremona et al. 2020) with increasing temperatures increasing metazooplankton abundance and biomass. Our results show that primary production was not limited by SRP,TP was not identified as a major predictor in the HP analyses and the GAMS show that chl-a decreased since the mid-1990s when we observed increasing SRP concentrations (Fig. 3c, Fig. 9a).

Zebra mussels do not appear to have had a large impact on the lake since they appeared in 2005. They are established in the Lough in low numbers and did not appear until 2005, well after the observed downward trend in phytoplankton biomass. They have not expanded well in the Lough due to lack of suitable habitat, poor water exchange between the originally infested bay and the rest of the lough, suboptimal water quality in the infested bay and the Allee effect (McLean 2012).

Our work demonstrates that a broader view would be helpful for river basin management plans, taking into account both external and internal sources and their characteristics in order to set achievable $\mathrm{P}$ targets. Lake water $\mathrm{N}$ concentrations were well correlated with $\mathrm{N}$ catchment inputs, however, despite no significant increase in catchment inputs of $\mathrm{P}$ we observed increasing $\mathrm{P}$ concentrations in the lake. The lack of correlation between inputs of $\mathrm{P}$ and lake water $\mathrm{P}$ means that measures in the catchment may have less impact than expected at lowering lake $\mathrm{P}$. The increase in lake water concentrations of $\mathrm{P}$ was likely brought about by the more prolonged and larger release of sediment $\mathrm{P}$ in the latter years of the data series. Subsequent changes in lake water stoichiometric composition influenced primary production. Our analyses of chl- $a$ show that although temperature has always been an important influence, changes have occurred and DIN has become an important predictor of chl-a concentrations after the mid-1990s, this, together with the log (DIN:TP) and $\log (\mathrm{chl}-a: \mathrm{TP})$ ratios support the case of increased $\mathrm{N}$ limitation of phytoplankton production in the lake. 


\section{ACKNOWLEDGMENTS}

This research was funded by the DAERA, Northern Ireland. The authors are grateful to all project and AFBI staff, past and present for their work on this long-term dataset. We are also grateful for the support of Wendy McKinley, Brenda Walker, Mary Gallagher, Paul Devine and Brian Ervine from DAERA NI. The authors wish to thank Prof. Bruce Osborne and two anonymous reviewers for their comments and suggestions which significantly improved this manuscript.

\section{REFERENCES}

Bergström,A.K. 2010 The use of TN:TP and DIN:TP ratios as indicators for phytoplankton nutrient limitation in oligotrophic lakes affected by $\mathrm{N}$ deposition. Aquatic Sciences 72, 277-81.

Bowman, A.W. and Azzalini, A. 2014 R package 'sm': nonparametric smoothing methods, 2.2-5.4 ed. R Package.

Carvalho, L. and Kirika, A. 2003 Changes in shallow lake functioning: response to climate change and nutrient reduction. Hydrobiologia 506, 789-96.

Chapman, B., Cooke, G.H. and Whitehead, R. 1967 Automated analysis: the determination of ammonical, nitrous and nitric nitrogen in river waters, sewage effluents and trade effluents. Journal of the Institute of Water Pollution Control 77, 478-91.

Chevan, A. and Sutherland, M. 1991 Hierarchical partitioning. American Statictician 45, 90-6.

Davison, W. 1993 Iron and manganese in lakes. Earth Science Reviews 34, 119-63

Ding et al. 2018 Internal phosphorus loading from sediments causes seasonal nitrogen limitation for harmful algal blooms. Science of the Total Environment 625, 872-84.

Eisenreich, S.J., Bannerman, R.T. and Armstrong, D.E. 1975 A simplified phosphorus analysis technique. Environmental Letters 9, 43-53.

European Commission 2000 Directive of the European Parliament and of the Council of 23 October 2000 establishing a framework for Community action in the field of water policy: Joint text approved by the Conciliation Committee. 1997/0067(COD) C5-0347/00. Commission for the European Communities (CEC).

European Environment Agency 2018 European waters - assessment of status and pressures 2018.

Ferguson et al. 2008 Assessing ecological responses to environmental change using statistical models. Journal of Applied Ecology 45, 193-203.

Fitzsimons, A.G. and Andrew,T.E. 1993 Seasonal succession of zooplankton. In R.B. Wood and R.V. Smith (eds), Lough Neagh: The ecology of a multipurpose water resource, 203-23. Dordrecht. Kluwer Academic Publishers.

Fletcher, C.L. 1990 The recent sedimentary history and contemporary budges of zinc, copper and lead in Lough Neagh, Northern Ireland. PhD thesis, University of Ulster.

Gerten, D. and Adrian, R. 2000 Climate-driven changes in spring plankton dynamics and the sensitivity of shallow polymictic lakes to the North Atlantic Oscillation. Limnology and Oceanography 45, 1058-66.
Gibson, C.E. 1993 The phytoplankton populations of Lough Neagh. In R.B. Wood and R.V. Smith (eds), Lough Neagh:The ecology of a multipurpose water resource, 203-23. Dordrecht. Kluwer Academic Publishers.

Gibson, C.E., Smith, R.V. and Stewart D.A. 1992 The Nitrogen cycle in Lough Neagh, N. Ireland 1975 to 1987. Internationale Revue der gesamten Hydrobiologie und Hydrographie 77, 73-83.

Gibson, C.E. and Stewart, D.A. 1993 Nutrient cycles in Lough Neagh. In R.B. Wood and R.V. Smith (eds), Lough Neagh:The ecology of a multipurpose water resource, 171-201. Dordrecht. Kluwer Academic Publishers.

Gibson, C.E., Wang, G., and Foy, R.H. 2000 Silica and diatom growth in Lough Neagh: the importance of internal recycling. Freshwater Biology 45, 285-93.

Gibson, C.E., Wang, G.X., Foy, R.H. and Lennox, S.D. 2001 The importance of catchment and lake processes in the phosphorus budget of a large lake. Chemosphere 42, 215-20.

Hastie, T. and Tibshirani, R. 1990 Exploring the nature of covariate effects in the porportional hazards model. Biometrics 46, 1005-16.

Helsel, D.R. 2005 Non-detects and data analysis: Statistics for censored environmental data. Hoboken, NJ. Wiley-Interscience.

Isles, P.D.F. 2020 The misuse of ratios in ecological stoichiometry. Ecology 101, e03153.

Jensen, H.S. and Andersen, F.O. 1992 Importance of temperature, nitrate and $\mathrm{pH}$ for phosphate release from aerobic sediments of four shallow, eutrophic lakes. Limnology and Oceanography 37, 577-89.

Johnes, P. 2007 Uncertainties in annual riverine phosphorus load estimation: Impact of load estimation methodology, sampling frequency, baseflow index and catchment population density. Journal of Hydrology 332, 241-58.

Köhler et al. 2005 Long-term response of a shallow, moderately flushed lake to reduced external phosphorus and nitrogen loading. Freshwater Biology 50, 1639-50.

Kolzau et al. 2014 Seasonal patterns of nitrogen and phosphorus limitation in four German lakes and the predictability of limitation status from ambient nutrient concentrations. Plos One 9.

Lee, L. 2013 NADA: Nondetects and data analysis for environmental data. $\mathrm{R}$ package.

MacNally, R. 1996 Hierarchical partitioning as an interpretative tool in multivariate inference. Australian Journal of Ecology 21, 224-28.

MacNally, R. 2000 Regression and model-building in conservation biology, biogeography and ecology: The distinction between - and reconciliation of- 'predictive' and 'explanatory' models. Biodiversity and Conservation 9, 655-71.

MacNally, R. 2002 Multiple regression and inference in ecology and conservation biology: Further comments on identifying important predictor variables. Biodiversity and Conservation 11, 1397-401.

McKean, C.J.P. 1986 The influence of lake and basin morphology on internal phosphorus loading in softwater lakes. Lake and Reservoir Management 2, 126-30.

McLean, S.P. 2012 Early colonisation of the zebra mussel (Dreissena polymorpha) in Lough Neagh: Ecological and socio-economic impacts for the rural eel fishing industry. Ph.D. thesis, Queen's University Belfast. 
Moore Jr, P.A. and Reddy K.R. 1994 Role of Eh and pH on phosphorus geochemistry in sediments of Lake Okeechobee, Florida. Journal of Environmental Quality 23, 955-64.

Moss et al.2005 Consequences of reduced nutrient loading on a lake system in a lowland catchment: deviations from the norm? Freshwater Biology 50, 1687-705.

Murphy, J. and Riley, J.P. 1962 A modified single solution method for the determination of phosphate in natural waters. Analytica Chimcia Acta 27, 31-6.

Nürnberg, G.K. 1987 A comparison of internal phosphorus loads in lakes with anoxic hypolimnia-laboratory incubations verusus insitu hypolimnetic phosphorus accumulation. Limnology and Oceanography 32, 1160-64.

Pettersson et al. 2003 Seasonality of chlorophyll and nutrients in Lake Erken-effects of weather conditions. Hydrobiologia 506, 75-81.

Phillips et al. 1994 The importance of sediment phosphorus release in the restoration of very shallow lakes (the Norfolk-Broads, England) and implications for biomanipulation. Hydrobiologia 275, 445-56.

Ptacnik, R., Andersen, T. and Tamminen, T. 2010 Performance of the Redfield Ratio and a family of nutrient limitation indicators as thresholds for phytoplankton $\mathrm{N}$ vs. P limitation. Ecosystems 13, 1201-14.

R Development Core Team 2014 R: A language and environment for statistical computing, $R$ Foundation for statistical computing. Vienna. Austria.

Redfield,A.C. 1958 The biological control of chemical factors in the environment. American Scientist 46, 5-221.

Rippey, B.H.R.T. 1980 The release of silicon and phosphorus from the sediments of Lough Neagh. Ph.D. thesis, University of Ulster.

Shatwell, T. and Köhler, J. 2019 Decreased nitrogen loading controls summer cyanobacterial blooms without promoting nitrogen-fixing taxa: Long-term response of a shallow lake. Limnology and Oceanography 64, S166-S178.

Smith, L., Watzin, M.C. and Druschel, G. 2011 Relating sediment phosphorus mobility to seasonal and diel redox fluctuations at the sediment-water interface in a eutrophic freshwater lake. Limnology and Oceanography 56, 2251-64.

Smith, R.V. 1993 Phosphorus and nitrogen loadings to Lough Neagh and their management. In R.B. Wood and R.V. Smith (eds), Lough Neagh: The ecology of a multipurpose water resource, 149-69. Dordrecht. Springer Netherlands.

Søndergaard, M., Jensen, J.P. and Jeppesen, E. 1999 Internal phosphorus loading in shallow Danish lakes. $\mathrm{H}_{\gamma}$ drobiologia 408, 145-52.

Søndergaard et al. 2007 Lake restoration: successes, failures and long-term effects. Journal of Applied Ecology 44, 1095-1105.

Søndergaard, M., Bjerring, R. and Jeppesen, E. 2013 Persistent internal phosphorus loading during summer in shallow eutrophic lakes. Hydrobiologia 710, 95-107.

Spears et al. 2013 Variation in chlorophyll- $a$ to total phosphorus ratio across $94 \mathrm{UK}$ and Irish lakes: Implications for lake management. Journal of Environmental Management 115, 287-94.

Stevens, R.J. 1976 Semi-automated ammonia probe determination of Kjeldahl nitrogen in freshwaters. Water Research 10, 171-75.

Talling, J.F. and Driver, D. 1963 Some problems in the estimation of chlorophyll-a in phytoplankton. Symposium on primary productivity measurements, marine and freshwater, U.S. Atomic Energy Commission TID-7633.

Walsh, C. and MacNally, R. 2013 hier.part: Hierarchical partitioning. $R$ package version 1.0-4.

Wood, S. 2017 Generalized additive models: An introduction with $R$. London/Boca Raton, FL, USA. Chapman and Hall/CRC.

Wood, R.B. and Smith R.V. (eds) 1993 Lough Neagh: The ecology of a multipurpose water resource, 149-69. Dordrecht. Springer Netherlands.

Wurtsbaugh, W.A., Paerl, H.W. and Dodds, W.K. 2019 Nutrients, eutrophication and harmful algal blooms along the freshwater to marine continuum. Wiley Interdisciplinary Reviews - Water 6, e1373. 
(a)

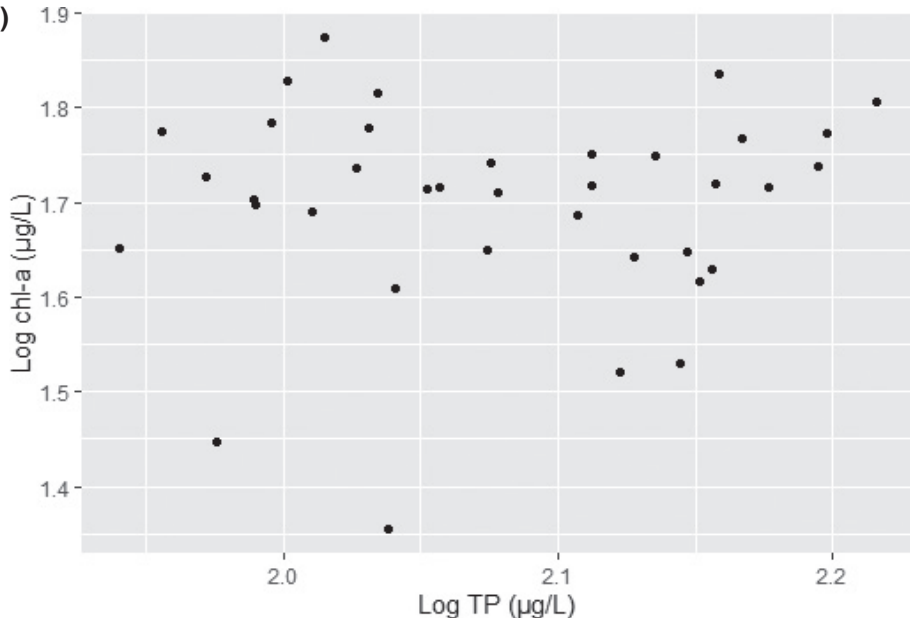

(b)

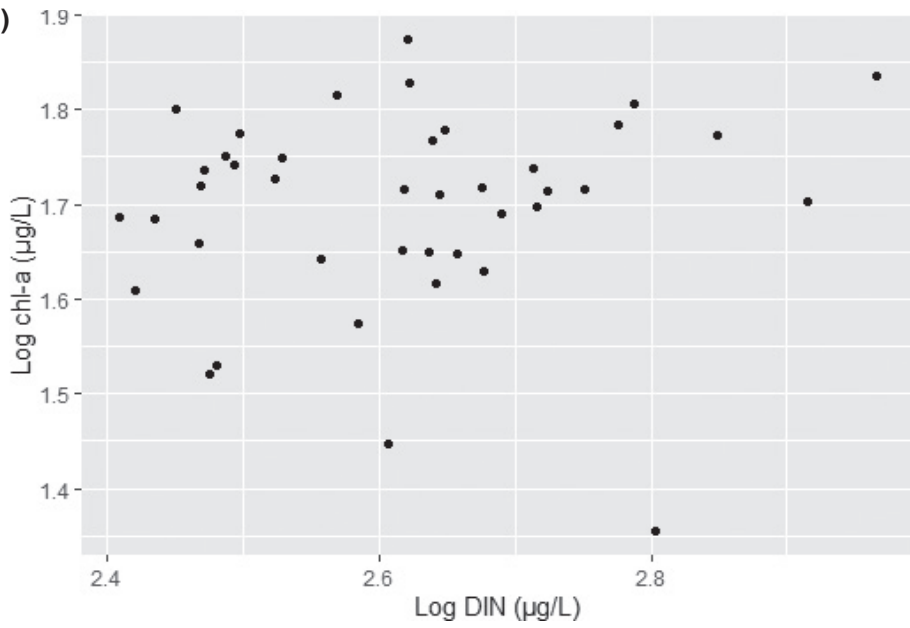

(c)

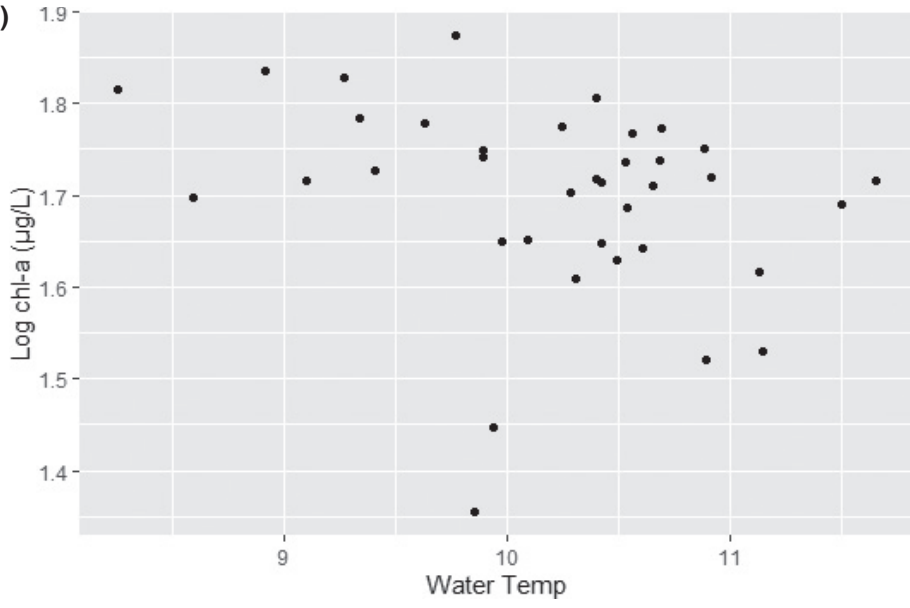

Appendix I-Log of annual mean chlorophyll- $a(\log$ chl-a, $\mu$ g/L), 1974 to 2012, plotted against: $\log$ of annual mean total P $(\log \mathrm{TP}, \mu \mathrm{g} / \mathrm{L}),(\mathrm{a}), \log$ of annual mean dissolved inorganic $\mathrm{N}(\mathrm{Log}$ DIN, $\mu \mathrm{g} / \mathrm{L}), \mathrm{n}=(\mathrm{b})$ and water temperature $(\mathrm{C})$ at $10 \mathrm{~m}$ depth (Water Temp) (c), $\mathrm{n}=37$. 


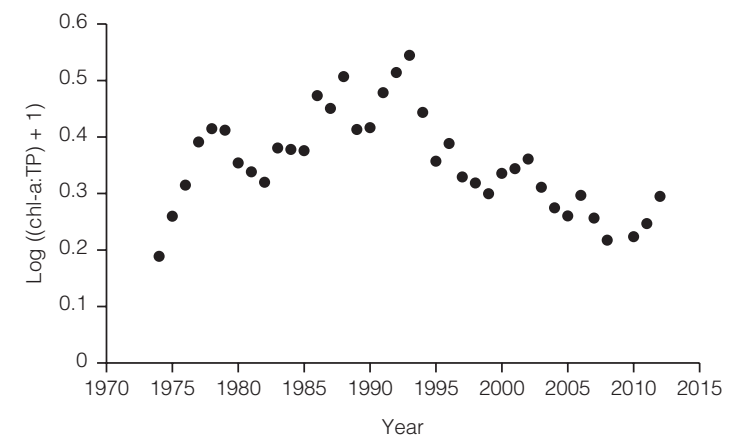

Appendix II-Log of annual mean $((\mathrm{chl}-a: \mathrm{TP})+1), 1974$ to $2012, \mathrm{n}=38$. 